Bangladesh J. Bot. 36(1): 39-46, 2007 (June)

\title{
MORPHOGENETIC AND DIURNAL VARIATION OF TOTAL PHENOLS IN SOME HYPERICUM SPECIES FROM TURKEY DURING THEIR PHENOLOGICAL CYCLES
}

\author{
Ali Kemal Ayan, Oguzhan Yanar ${ }^{1}$, Cuneyt Cirak ${ }^{2 *}$ and Mahmut Bilgener ${ }^{1}$ \\ The High School of Profession of Bafra, University of Ondokuz Mayıs, Samsun, Turkey
}

Key words: Hypericum sp., Diurnal variation, Total phenols, Phenological cycles

\begin{abstract}
The genus Hypericum has attracted scientific interest worldwide in recent years, since it is a source of a variety of biologically active compounds including the phenolics. The present study was to determine ontogenetic, morphogenetic and diurnal variation of the total phenol contents in some Hypericum species growing in Turkey namely, $H$. nummularioides, $H$. hyssopifolium, $H$. pruinatum and $H$. scabrum. Plants were separated into stem, leaf and reproductive tissues, which were dried separately, and subsequently assayed for total phenol contents. Among different tissues, leaves had higher phenol contents and the highest content reached at noon in all species tested. But, ontogenetic change in the total phenol contents of whole plants varied among the species. It reached the highest level at floral budding in H. hyssopifolium and H. scabrum, at full flowering in $H$. pruinatum and at fresh fruiting in $H$. nummularioides.
\end{abstract}

\section{Introduction}

The genus Hypericum contains approximately 400 different species of annuals, perennials, shrubs and small trees, ranging from very small perennials to trees. The species of this genus have been used as healing agent due to their various medicinal properties for the last two hundred years (Dias et al. 1998). Hypericum species are also used as sedatives, antiseptics, and antispasmodics in Turkish folk medicine under the names "kantaron, peygamber çiçeği, kılıçotu, kanotu, kuzukıran and binbirdelik otu" (Baytop 1999). The Hypericum genus is represented in Turkey by 89 species of which 43 are endemic. The most widespread and abundant species is $H$. perforatum L. (Davis 1988).

Morphologically, Hypericum plants are characterised by the presence of different kinds of secretory tissues including light glands, dark glands and secretory canals. These secretory structures are sites of synthesis and/or accumulation of biologically active substances and their localizations are different depending on plant tissue (Cicracelli et al. 2001). Therefore, organdependence of phenolic compounds has an important role to the understanding of the underlying sources of variation in phenolic contents of Hypericum plants.

Methanolic extract from the aerial parts of Hypericum plants typically contains hypericins, hyperforins and phenolic compounds (Barnes et al. 2001). It is especially rich in phenolics, caffeic acid, chlorogenic acid, proanthocyanidin (dimers and oligomers of catechin and epicatechin), prenylated derivatives of phloroglucinol and flavonoids, hyperin, rutin, quercitrin, isoquercitrin and bis-apigenins. (Mojca et al. 2005). Phenolic compounds are important for their contribution to the colour, sensory attributes and nutritional and antioxidant properties of plants (Christel et al. 2000). Phenolic compounds are reported to have multiple biological effects, including antioxidant activity, antitumor, antimutagenic and antibacterial properties (Shui and Leong 2002).

Diurnal fluctuations in the concentration of plant secondary metabolites such as saponins in Phytolacca dodecandra (Ndamba et al. 1993), alkaloids in Papaver somniferum (Itenov et al. 1999), essential oils in Laurus nobilis (Kevseroğlu et al. 2003) and hypericins in H. perforatum,

*Corresponding author: E-mail: cuneytc@ omu.edu.tr . ${ }^{1}$ Department of Biology, Faculty of Science and Art, University of Ondokuz May1s, Kurupelit, Samsun, Turkey. ${ }^{2}$ Department of Agronomy, Faculty of Agriculture, University of Ondokuz May1s, Kurupelit, Samsun, Turkey. 
H. pruinatum and H. aviculariifolium (Çırak et al. 2006) have been reported. However, there is no information about diurnal variation of phenols in species of Hypericum.

Increased market demand for Hypericum plants has led to several investigations of secondary metabolite levels in plants from different areas of the world. These previous investigations were carried out on $H$. perforatum and did not give homogenous results. Furthermore, they are fully related with hypericins (Sirvent et al. 2002), hyperforin (Kirakosyan et al. 2002) or essential oils (Schwob et al. 2004) and ontogenetic stages were not established in most of them. To date, little effort has been given to the study of variation of phenolic compounds such as quercitrine, isoquercitrine (Marfonti and Repcak 1994) and quercetin (Tekel'ova et al. 2000). To our knowledge, no study has been done on the variation of total phenols in $H$. nummularioides Trautv., H. hyssopifolium Chaix, H. pruinatum Boiss.\& Bal. and H. scabrum L.

In the present study, morphogenetic and diurnal variations of total phenols were investigated in the four Turkish species of Hypericum at different stages of plant phenology. The aim was to determine if there was a link between phenol content of plant materials and development stages during diurnal and phenological cycles.

\section{Materials and Methods}

H. nummularioides: Stems 10-20 cm, erect or ascending from a branching base, not rooting, glabrous. Leaves 7-15 mm, ovate to oblong-elliptic, plane, glabrous with conspicuous intramarginal glands. Inflorescence corymbose, 1-5 flowered. Sepals ovate to oblong-elliptic, black-glandular-denticulate. Petals 10-16 mm. Capsule unknown.

H. hyssopifolium: Stems $15-80 \mathrm{~cm}$, erect, glabrous or with minute red or amber glands. Leaves on main stem 10-30 mm, narrowly elliptic-oblong to linear, often revolute. Inflorescence elongate, narrowly cylindiric to pyramidal, many-flowered. Sepals unequal or subequal, ovate to oblong or rarely lanceolate, entire or with sessile glands. Petals 8-16 mm, sometimes red-veined. Capsule 5-15 mm, ovoid to subglobose.

H. scabrum: Stems $15-45 \mathrm{~cm}$, erect or decumbent at the base, glabrous, scabrid with unbranched red-gland-tipped emergences. Leaves on main stems 7-20 mm, oblong or oblongelliptic to lanceolate or linear. Inflorescence corymbose, many-flowered. Sepals oblong, subacute to rounded. Petals 5-8 mm. Capsule 5-8 mm, ovoid or ovoid-rigonous, not or scarcely rostrate.

H. pruinatum: Stems $15-35 \mathrm{~cm}$, erect or ascending from a rooting and branching base, pruinose. Leaves on main stems $10-35 \mathrm{~mm}$, oblong to elliptic, pruinaose. Inflorescence pyramidal to cyclindric. Sepals broadly oblong to broadly elliptic, rounded, entire or minutely blackglandular-denticulate. Petals 9-14 mm. Capsule7-10 mm, ovoid (Davis 1988). The plant materials were identified and Voucher specimens were deposited in the Herbarium of Agricultural Faculty, Ondokuz Mayis University.

The Hypericum plants were collected from mountain pasture of Kuşmer in Aydintepe district of Bayburt province ( $40^{\circ} 15^{\prime} \mathrm{N}$ Lat., $40^{\circ} 14^{\prime}$ E Long., and $1884 \mathrm{~m}$ elevation), Turkey between May and September of 2004 at different stages of plant development. The sampling sites were not grazed or mown during the sampling periods. Collections were done three times a day $(06.00$, 12.00 and $18.00 \mathrm{~h}$ ) for each development stage. Sampling was done in these wild populations by a randomized collection of 30 individuals for each collection time within a day and each phenological stage.

Shoots with leaves were harvested at the vegetative stage. For the floral budding stage, only shoots with floral buds were selected. At the full flowering stage, only shoots with full opened flowers were harvested. At the fresh fruiting stage, the shoots which had green capsules were harvested. At the mature fruiting stage, the shoots which had dark brown capsules were harvested. After collection, ten individuals were kept as whole plants and the rest were separated into floral, 
leaf and stem tissues. The plant materials were dried at room temperature $\left(20 \pm 2^{\circ} \mathrm{C}\right)$ separately. The dried materials were bulked and subsequently assayed for total phenols.

The procedure of Swain and Hills (1959) was used to determine the total phenolic contents of the plant extract. The total phenolics were measured in a spectrophotometer at $725 \mathrm{~nm}$. A reagent blank and tannic acid blank and a sample blank were prepared. All samples and tannic acid standard solutions $(0.01$ to $0.06 \mathrm{mg} / \mathrm{ml})$ were tested in triplicate and the mean value was calculated.

Phenol content of plant materials was given for each species. Data for phenol content of whole plant were objected to ANOVA and significant differences among phenol contents were tested with the DMRT $(\mathrm{p}<0.01)$. However, because of the absence of generative tissues at vegetative stage as an experimental factor, no statistical analysis was performed for data belonging to the phenol content of different plant tissues (Steel and Torrie 1980).

\section{Results and Discussion}

Total phenolic contents of plant tissues varied with species greatly. H. nummularioides had the highest phenolic content and approximately eightfold difference between total phenol contents of this species and that of $H$. scabrum, supplying the lowest value.

Change in phenol content of whole plant within a day during the course of ontogenesis did not follow the same trend in the four species of Hypericum. In H. hyssopifolium and H. scabrum, phenol content in whole plant increased during flower ontogenesis and reached their highest level at floral budding (1.92 and $0.24 \% \mathrm{DW}$, respectively), then it decreased. The difference among phenol contents in whole plant at different development stages was found to be significant ( $\mathrm{p}<$ 0.01). Diurnal fluctuation in phenol content of whole plant was also observed for $H$. hyssopifolium and it was highest $(1.68 \% \mathrm{DW})$ at noon (Table 1). Similarly, phenol contents in whole plant were statistically different among different developmental stages in $H$. pruinatum and $H$. nummularioides $(\mathrm{p}<0.01$ ) but the highest concentration reached at full flowering for $H$. pruinatum $(0.71 \% \mathrm{DW})$ and fresh fruiting for $H$. nummularioides. Similar to $H$. hyssopifolium, a significant difference was detected in phenol content in whole plant among diurnal harvesting and it was highest ( 0.63 and $1.73 \%$ DW, respectively) at noon in both species (Table 1).

Ontogenetic and diurnal fluctuations in phenol content of stems, leaves and reproductive parts varied with plant tissues and species. Leaves had higher phenolic content when compared to other tissues and total phenols content of all tissues was the highest at noon for all species. Leaf samples collected at noon gave the highest values depending on phenological stage in $H$. nummularioides, H. hyssopifolium and H. pruinatum, 2.36, 2.09 and 0.89\% DW, respectively (Figs.1, 2 and 3). Similarly, total phenols content of leaves was generally higher than that of other tissues in $H$. scabrum during its phenological cycle, although the highest value $(0.32 \% \mathrm{DW})$ for this species was obtained from floral buds collected at noon (Fig. 4).

Investigations of ontogenetic variation of secondary metabolites have been made over several decades, e.g. alkaloid changes during fruit development in Papaver somniferum (Miriam and Pfeifer 1959) and Conium maculatum (Fairbairn and Challen 1959), essential oil changes during the course of ontogenesis in Hypericum perforatum (Schwob et al. 2004), artemisinin changes during phenological cycle of Artemisia апnиа (Gupta et al. 2002) and foliar monoterpenoid variation in Umbellularia californica in seedlings, saplings and adult trees stages (Raymond et al. 1996). Chemical concentrations vary considerably during the course of ontogenesis in a medicinal plant, not only do the concentrations of plant chemicals fluctuate through the season, but they can also be short-lived and experience rapid turnover. (Smith et al. 1996). Likewise, in the present study, total phenol contents of whole plants at different phenological stages were significantly different for each Hypericum species and the highest levels reached at different stages of plant 
phenology depending on species (Kazlauskas and Bagdonaite 2004). Similarly, Osisnka and Weglarz (2003). Ontogenetic fluctuations in phenolic content were also reported for other plant species such as Malus domestica (Treutter 2001), Morus alba and Morus nigra (Sivaci and Sökmen 2004).

Table 1. Variation of total phenol contents of Hypericum hyssopifolium, $\mathrm{H}$. scabrum, $\mathrm{H}$. pruinatum and $H$. nummularioides within a day during the course of ontogenesis (\% DW).

\begin{tabular}{|c|c|c|c|c|}
\hline \multicolumn{5}{|c|}{ H. hyssopifolium } \\
\hline \multirow{2}{*}{ Developmental stages } & \multicolumn{4}{|c|}{ Diurnal collecting times } \\
\hline & $06.00 \mathrm{~h}$ & $12.00 \mathrm{~h}$ & $18.00 \mathrm{~h}$ & Mean \\
\hline Vegetative & $1.11 \mathrm{o}^{*}$ & $1.34 \mathrm{ikl}$ & $1.06 \mathrm{o}$ & $1.17 \mathrm{D} * *$ \\
\hline Floral budding & $1.85 \mathrm{ab}$ & $2.00 \mathrm{a}$ & $1.91 \mathrm{ab}$ & $1.92 \mathrm{~A}$ \\
\hline Full flowering & $1.17 \mathrm{~nm}$ & $1.67 \mathrm{bcd}$ & $1.31 \mathrm{kl}$ & $1.38 \mathrm{CD}$ \\
\hline Fresh fruiting & $1.70 \mathrm{bcd}$ & $1.85 \mathrm{ab}$ & $1.68 \mathrm{bcd}$ & $1.74 \mathrm{~B}$ \\
\hline Mature fruiting & $1.38 \mathrm{ik}$ & $1.55 \mathrm{f}-\mathrm{i}$ & $1.42 \mathrm{~h}-\mathrm{k}$ & $1.45 \mathrm{C}$ \\
\hline Mean & $1.44 \mathrm{~B}$ & $1.68 \mathrm{~A}$ & $1.47 \mathrm{~B}$ & \\
\hline \multicolumn{5}{|c|}{ H. scabrum } \\
\hline Vegetative & $0.12 \mathrm{~d}^{*}$ & $0.18 \mathrm{abc}$ & $0.18 \mathrm{abc}$ & $0.15 \mathrm{~B} * *$ \\
\hline Floral budding & $0.22 \mathrm{ab}$ & $0.28 \mathrm{a}$ & $0.23 \mathrm{ab}$ & $0.24 \mathrm{~A}$ \\
\hline Full flowering & $0.17 \mathrm{bc}$ & $0.21 \mathrm{ab}$ & $0.20 \mathrm{ab}$ & $0.19 \mathrm{AB}$ \\
\hline Fresh fruiting & $0.15 \mathrm{bc}$ & $0.19 \mathrm{abc}$ & $0.17 \mathrm{bc}$ & $0.17 \mathrm{~B}$ \\
\hline Mature fruiting & $0.14 \mathrm{bc}$ & $0.15 \mathrm{bc}$ & $0.12 \mathrm{~d}$ & $0.14 \mathrm{~B}$ \\
\hline Mean & 0.16 & 0.20 & 0.18 & \\
\hline \multicolumn{5}{|c|}{ H. pruinatum } \\
\hline Vegetative & $0.62 \mathrm{bc}^{*}$ & $0.67 \mathrm{~b}$ & $0.53 \mathrm{~cd}$ & $0.61 \mathrm{~B} * *$ \\
\hline Floral budding & $0.55 \mathrm{~cd}$ & $0.61 \mathrm{bc}$ & $0.54 \mathrm{~cd}$ & $0.56 \mathrm{AB}$ \\
\hline Full flowering & $0.72 a b$ & $0.78 \mathrm{a}$ & $0.61 \mathrm{bc}$ & $0.71 \mathrm{~A}$ \\
\hline Fresh fruiting & $0.66 \mathrm{~b}$ & $0.67 \mathrm{~b}$ & $0.60 \mathrm{bc}$ & $0.64 \mathrm{~B}$ \\
\hline Mature fruiting & $0.27 \mathrm{f}$ & $0.41 \mathrm{e}$ & $0.33 \mathrm{f}$ & $0.34 \mathrm{C}$ \\
\hline Mean & $0.56 \mathrm{AB}$ & $0.63 \mathrm{~A}$ & $0.52 \mathrm{~B}$ & \\
\hline \multicolumn{5}{|c|}{ H. nummularioides } \\
\hline Vegetative & 1.19 ghi* & $1.39 \mathrm{fg}$ & $1.02 \mathrm{i}$ & $1.20 \mathrm{D} * *$ \\
\hline Floral budding & $1.30 \mathrm{gh}$ & $1.92 \mathrm{~b}$ & $1.71 \mathrm{~d}$ & $1.64 \mathrm{~B}$ \\
\hline Full flowering & $1.62 \mathrm{de}$ & $1.71 \mathrm{~d}$ & $0.89 \mathrm{i}$ & $1.41 \mathrm{C}$ \\
\hline Fresh fruiting & $1.91 \mathrm{ab}$ & $2.10 \mathrm{a}$ & $1.92 a b$ & $1.98 \mathrm{~A}$ \\
\hline Mature fruiting & $1.51 \mathrm{ef}$ & $1.54 \mathrm{ef}$ & $1.44 \mathrm{efg}$ & $1.49 \mathrm{C}$ \\
\hline Mean & $1.51 \mathrm{~B}$ & $1.73 \mathrm{~A}$ & $1.40 \mathrm{C}$ & \\
\hline
\end{tabular}

Values followed by same small letters and capital letters do not differ significantly at $1 \%$ level.

Plant material representing a total of ten individuals includes leaves and stems for vegetative stage; reproductive parts, leaves and stems for floral budding; full flowering; fresh fruiting stages; stems, brown capsules with seeds for mature fruiting stages.

Similar to primary metabolites, tissue-dependence of secondary metabolites is very common among medicinal plants. Leaves and flowers generally contain greater levels of phenolic acids and terpenoids than stems and roots (Hakulinen and Julkunen-Tiitto 2000). In the present study, leaves had the highest level of total phenols in all species tested and similar findings were reported by Radusiene et al. (2004) and Valentao et al. (2003). 


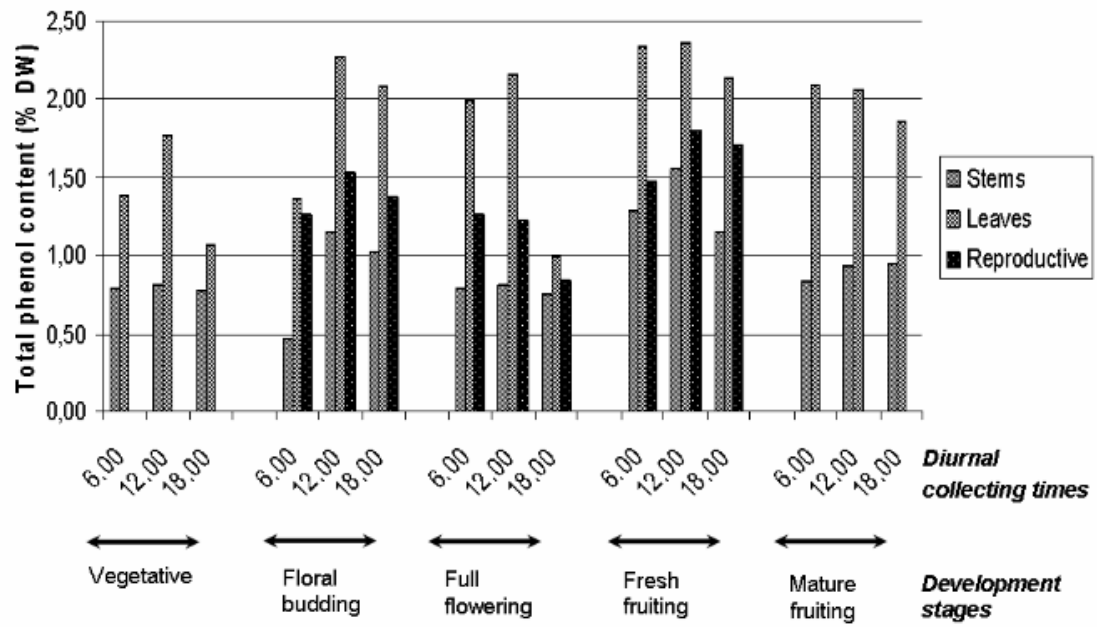

Fig. 1. Diurnal and ontogenetic changes in total phenol contents of reproductive parts, leaf and stem tissues in $H$. nummularioides.

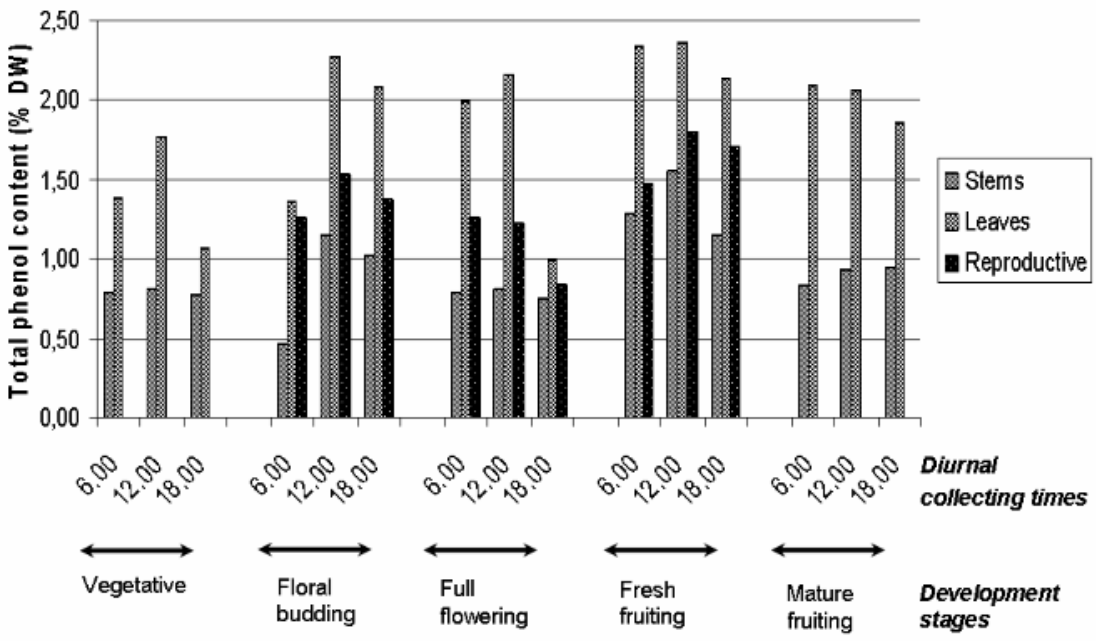

Fig. 2. Diurnal and ontogenetic changes in total phenol contents of reproductive parts, leaf and stem tissues in H. hyssopifolium.

Although, the general role of phenolic compounds in plant physiology and allelopathy has been known for many years, a less well reported aspect is their activity as defence factors against various types of stresses caused by pathogens or adverse environmental conditions (Treutter 2001). Plants can accumulate phenolic compounds in their different tissues in response to challenge by various stress factors (Pasqualini et al. 2003). During the course of ontogenesis, plants are subjected to different kinds of stress factors, such as drought, heat, herbivore/pathogen attack and air pollution (Paliyath et al. 1997). Most plants suffer from physiological and biochemical damage due to the exposure to temperatures higher or lower than optimal for growth (Grace et al. 1998). Climatic changes like high temperature stress promote production of phenolic compounds (Christie et al. 1994, Dixon and Paiva 1995, Sivacı and Sökmen 2004). The increase 
observed here in phenolic content of plant tissues of the Turkish Hypericum species collected at noon may be attributed to higher temperatures of midday.

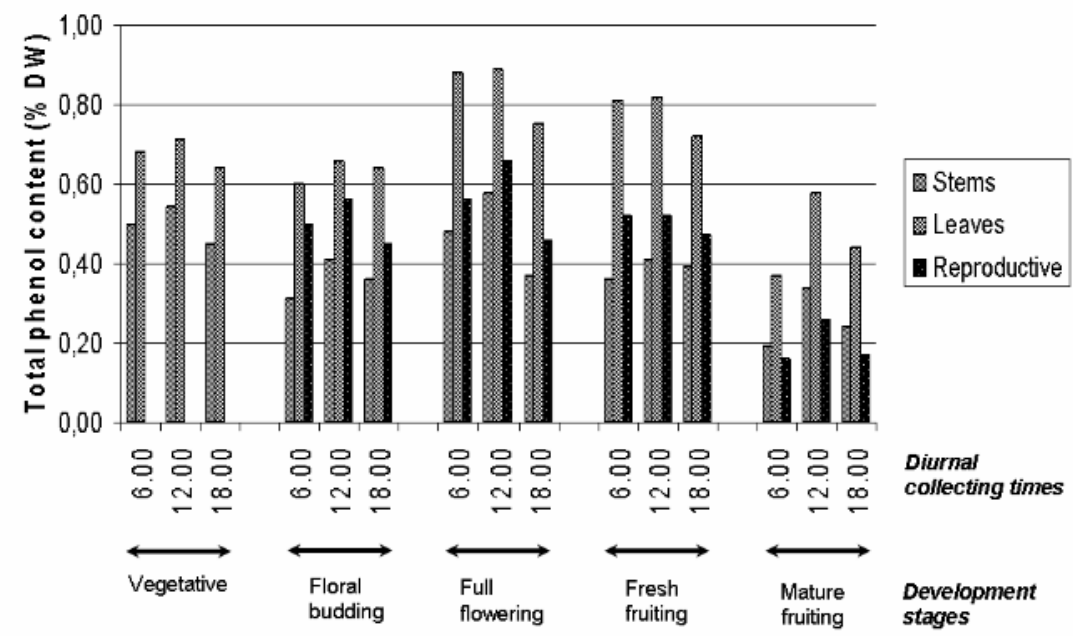

Fig. 3. Diurnal and ontogenetic changes in total phenol contents of reproductive parts, leaf and stem tissues in $H$. pruinatum.

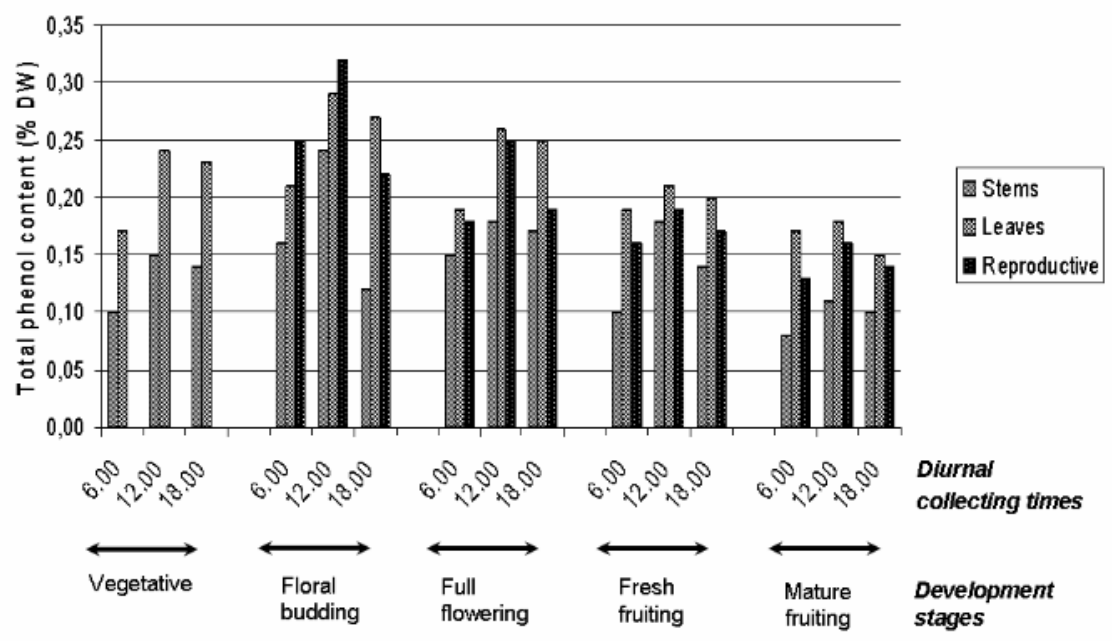

Fig. 4. Diurnal and ontogenetic changes in total phenol contents of reproductive parts, leaf and stem tissues in H. scabrum.

\section{Conclusion}

It can be concluded that there is a close relationship between phenolic content of plant tissues and growth stages during diurnal and phenological cycles in Hypericum species. Considering the pharmacological significance of phenolics, their possible use in therapeutics and the growing interest in analytical data on natural phenols in plants, it is important to find the different sources of these compounds. At this point, the high phenolic content of $H$. nummularioides and $H$. hyssopifolium encourages the cultivation, and biological evaluation of these species in Turkey. 
The results also indicated that the quantitative variation of total phenol contents in four Turkish species of Hypericum allows the selection of the best plant samples for their cultivation and conservation in field collections. Therefore, wild populations of these Hypericum species are potentially important sources for breeding and improvement of the cultivated varieties.

\section{References}

Barnes, J., L.A. Anderson and J.D. Phillipson. 2001. St John's wort (Hypericum perforatum L.), review of its chemistry, pharmacology and clinical properties. J. Pharm. Pharmacol. 53: 583-600.

Baytop, T. 1999. Therapy with medicinal plants in Turkey, Istanbul Univ. Press, stanbul, Turkey, pp. 452.

Chrestel, Q., G. Bernard, V. Jacques and B.M. Claude. 2000. Phenolic compounds and antioxidant activities of buckwheat (Fagopyrum esculentum Moench) hulls and flour. J. Ethnopharmacol. 72: 35-42.

Christie, P.J., M.R. Alfenito and V. Walbot. 1994. Impact of low-temperature stress on general phenylpropanoid and anthocyanin pathways, enhancement of transcript abundance and anthocyanin pigmentation in maize seedlings. Planta 194: 541-549.

Cicracelli, D., A.C. Andreucci and A. Pagni. 2001. Translucent glands and secretory canals in Hypericum perforatum, Morphological, anatomical and histochemical studies during the course of onthogenesis. Ann. Bot.-London. 88: 637-644.

Çırak, C., B. Sağlam, A.K. Ayan and K. Kevseroğlu. 2006. Morphogenetic and diurnal variation in some Hypericum species from Turkey during the course of ontogenesis. Biochem. Syst. Ecol. 34: 1-13.

Davis, P.H. 1988. Flora of Turkey and the East Aegean Islands. Edinburgh University Press, Edinburgh. $287-$ $290 \mathrm{pp}$.

Dias, A.C.P., A. Francisco, T. Barberian, F. Ferreria and F. Ferreres. 1998. Unusual flavanoids produced by callus of Hypericum perforatum. Phytochemistry. 48: 1165-1168.

Dixon, R.A. and N.L. Pavia. 1995. Stress-induced phenylpropanoid metabolism. Plant Cell. 7: 1085-1097.

Fairbairn, J.W. and S.B. Challen. 1959. Alkaloids of Hemlock (Conium maculatum L.) distribution in relation to the development of the fruit. Biochem. 72: 556-562.

Grace, S.C., B.A. Logan and W.W. Adams. 1998. Seasonal differences in foliar content of chlorogenic acid, a phenylpropanoid antioxidant, in Mahonia repens. Plant Cell Environ. 21: 513-521.

Gupta, S.K., P. Singh, P. Bajpai, G. Ram, D. Singh, M.N. Gupta, D.J. Jain, S.P. Khanuja and S. Kumar. 2002. Morphogenetic variation for artemisinin and volatile oil in Artemisia annua. Ind. Crop. Prod. 16: $217-$ 224.

Hakulinen, J. and R. Julkinen-Tiitto. 2000. Variation in leaf phenolics of field-cultivated willow (Salix myrsinifolia) clones in relation to occurrence of Melampsora rust. Forest Pathol. 30: 29-41.

Itenov, K., P. Mqlgaard and U. Nyman. 1999. Diurnal fluctuations of the alkaloid concentration in latex of poppy Papaver somniferum is due to day-night fluctuations of the latex water content. Phytochem. 52: 1229-1234.

Kazlauskas, S. and E. Bagdonaite. 2004. Quantitative analysis of active substances in St. John's wort (Hypericum perforatum L.) by the high performance liquid chromatography method. Medicina (Kaunas). 40: 975-981.

Kevseroğlu, K., C. Çırak and G. Özyazıcı. 2003. A study on ontogenetic and diurnal variability of Laurel (Laurus nobilis L.) leaves. Turkish J. Field Crop 8: 29-33.

Kirakosyan, A., D. Gibson and T. Sirvent. 2002. Comperative survey of Hypericum perforatum plants as sources of hypericins and hyperforin. J. Herbs, spices. Med. Plants. 10: 110-122.

Marfonti, P. and M. Repcak. 1994. Secondary metabolites during flower ontogenesis of Hypericum perforatum L. Zahradnictvi. 21: 37-44.

Miriam, R. and S. Pfeifer. 1959. Über die Veranderungen im Alkaloidhaushalt der Mohnpfanze warend einer Vegetationsperiode. Sci. Pharm. 27: 34-40.

Mojca, S., K. Petra, H. Majda, R. Aandreja, S. Marjana and Z. Knez. 2005. Phenols, proanthocyanidins, flavones and flavonols in some plant materials and their antioxidant activities. Food Chem. 89: 191-198. 
Ndamba, J., E. Lemmich and P. Mqlgaard. 1993. Investigation of the diurnal, ontogenetic and seasonal variation in the molluscicidal saponin content of Phytolacca dodecandra aqueous berry extracts. Phytochem. 35: 95-99.

Osisnka, E. and Z. Weglarz. 2003. Morphological, developmental and chemical variability of Hypericum genus. ISHS Acta Horticulturae 523.

Paliyath, G., R.G. Pinhero, M.V. Rao, D.P. Murr, R.A. Fletcher. 1997. Changes in activities of antioxidant enzymes and their relationship to genetic and paclobutrazol-induced chilling tolerance in maize seedlings. Plant Physiol. 114: 695-704.

Pasqualini, V., C. Robles, S. Garzino, S. Greff, A. Bousquet-Melou and G. Bonin. 2003. Phenolic compounds content in Pinus halepensis Mill needles, a bioindicator of air pollution. Chemosphere. 52: 239-248.

Radusiene, J., E. Bagdonaite and S. Kazlauskas. 2004. Morphological and chemical evaluation on Hypericum perforatum and $H$. maculatum in Lithuania. Acta Hort. (ISHS) 629: 55-62.

Raymond, J., L. Goralka and H.J. Langenheim. 1996. Implications of foliar monoterpenoid variation among ontogenetic stages of the California Bay Tree (Umbellularia californica) for deer herbivory. Biochem. Syst. Ecol. 24: 13-23.

Schwob, I., B. Jean-Marie, M. Veronique and V. Josette. 2004. Changes in essential oil composition in Saint John's wort (Hypericum perforatum L.) aerial parts during its phenological cycle. Biochem. Syst. Ecol. 32: 735-745.

Shui, G. and L.P. Leong. 2002. Separation and determination of organic acids and phenolic compounds in fruit juices and drinks by HPLC. J. Chromatogr. 77: 89-96.

Sirvent, T., L. Walker, N. Vance and D. Gibson. 2002. Variation in hypericins from wild populations of Hypericum perforatum L. in the Pacific Northwest of the U.S.A. Econ. Bot. 56: 41-49.

Sivaci, A. and M. Sökmen. 2004. Seasonal changes in antioxidant activity, total phenolic and anthocyanin constituent of the stems of two Morus species (Morus alba L. and Morus nigra L.). Plant Growth Regul. 44: 251-256.

Smith, R., D. Caswell, A. Carriere and B. Zielke. 1996. Variation in the ginsenoside content of American ginseng, Panax quinquefolius L. roots. Can. J. Bot. 74:1616-1620.

Steel, R.G. and J.H. Torrie. 1980. Principles and procedures of statistics. McGraw- Hill Book Co., New York.76 pp.

Swain, T. and W.E. Hills. 1959. The phenolic constituents of Prunus domestica. J. Agric. Food Chem. 10: 63-68.

Tekel'ova, D., M. Repcak, E. Zemkova and J. Toth. 2000. Quantitative changes of dianthrones, hyperforin and flavonoids content in the flower ontogenesis of Hypericum perforatum. Planta Med. 66: 778-780.

Treuter, D. 2001. Biosynthesis of phenolic compounds and its regulation in apple. Plant Growth Regul. 34: 71-89.

Valentao, P., A. Dias, M. Ferreira, B. Silva, P.B. Aandre, M.L. Bastos and R.M. Seabra. 2003. Variability in phenolic composition of Hypericum androsaemum. Nat. Prod. Res. 17: 135-140. 